\title{
DESPRE ENERGIE ALTFEL. TIPURI DE SPAȚII ARHITECTURALE CONTEMPORANE CA SUPORT PENTRU KINETOTERAPIE
}

\author{
DIFFERENT ABOUT ENERGY. TYPES OF \\ CONTEMPORARY ARCHITECTURAL SPACES AS \\ SUPPORT FOR KINETOTHERAPY
}

şef de lucrări dr. arh./ lecturer PhD. arch. Mihaela Zamfir (Grigorescu) $)^{1}$

masterand kinetoterapeut/masterand physical therapist Dragoș-Cristian Bogdan ${ }^{2}$

${ }^{1}$ Departamentul "Sinteza Proiectării de Arhitectură", Facultatea de Arhitectură, Universitatea de Arhitectură și Urbanism "Ion Mincu", București, România

"Synthesis of Architectural Design " Department, Faculty of Architecture, "Ion Mincu" University of Architecture and Urbanism, Bucharest, Romania

${ }^{2}$ Master "Kinetoterapia în afecțiunile locomotorii", Universitatea "Spiru Haret", București, România

Master "Kinetotherapy in locomotor diseases", "Spiru Haret" University, Bucharest, Romania

mmg_architecturestudio@yahoo.com / bogdandragoscristian@yahoo.com 


\section{Rezumat}

BACKGROUND: Kinetologia medicală are ca obiect de studiu mecanismele neuromusculare și articulare care asigură omului activitățile motrice normale. În același timp se preocupă de înregistrarea, analizarea și corectarea mecanismelor neuro-musculo-articulare deficitare. Kinetoterapia, terapia prin mișcare se diferențiază astăzi în trei componente- kinetoterapie profilactică, terapeutică și de recuperare şi are 9 obiective principale: 1. Relaxarea; 2. Corectarea posturii şi aliniamentului corpului; 3. Creşterea mobilităţii articulare; 4. Creşterea forţei musculare; 5. Creşterea rezistenţei musculare; 6. Coordonarea, controlul şi echilibrul; 7. Antrenarea la efort; 8. Reeducarea respiratorie; 9. Reeducarea sensibilităţii.

Kinetoterapia are nevoie de spații adecvate în care să se desfășoare, arhitectura contribuind în mod sinergic la creșterea eficacității procedurilor efectuate în cadrul unei astfel de terapii.

MATERIALE ȘI METODE: Au fost identificate tipuri de clădiri care conțin spaţii dedicate în care se poate practica kinetoterapie: spitate, clinici, centre de reabilitare, mici centre private, piscine terapeutice. În acest scop, au fost selectate exemple relevante din punctul de vedere al arhitecturii contemporane, evidențiindu-se trasăturile specifice atât pentru spații interioare cât și pentru spaţii exterioare: Physiotherapy and Rehabilitation Centre PUR / Schneider \& Lengauer, Therapeutic Pools for La Esperanza School / FUSTER + Architects, Vandhalla" Egmont Rehabilitation Centre / CUBO Arkitekter + Force4 Architects, Rehabilitation Centre Groot Klimmendaal / Koen van Velsen, Sport and Fitness Center for Disabled People / Baldinger Architectural Studio, Musholm Extension / AART architects, Center for Individuals with Disabilities / g.bang architecture. Au fost analizate proiectele acestor clădiri, descrierile proiectelor și fotografiile cu situația existentă.

REZULTATE: Patru elemente arhitecturale au fost identificate ca fiind semnificative în conturarea acestor tipuri de spații destinate terapiei prin mișcare: lumina, forma, culoarea și textura. Arhitectura contemporană dedicată kinetoterapiei utilizează principii din Designul Universal, promovând accesibilitatea persoanelor fragile, cu dizabilități, vârstnice sau copii. Formele diferă, de la spații rectangulare până la cele cu o geometrie fluidă. Lumina joacă întotdeauna un rol important, atât cea naturală cât și cea artificială, un grad de iluminare generos are efecte benefice asupra organismului uman, fototerapia influențând pozitiv rezultatele terapiei prin mișcare. Paleta cromatică este de asemenea importantă, sunt culori care activează precum portocaliu, roșu sau altele care relaxează precum verde, albastru. Textura suprafețelor pe care se lucrează joacă un rol esențial, sunt de evitat suprafețele care pot determina accidentări sau alunecări. De asemenea, aparatele și accesoriile în kinetoterapie sunt importante: scripeți, figuri și rulouri din tapițerie, plăci de echilibru din lemn și plastic, saltele, scări fixe/spaliere, mese pentru terapie ocupațională, bastoane și gantere. Kinetoterapia poate fi practicată și în spații exterioare care de asemenea trebuie amenajate utilizând aceleaşi 4 instrumente arhitecturale.

CONCLUZII: Rezultatele kinetoterapiei sunt potențate de calitatea spaţiului în care se desfăşoară. Eficiența procedurilor este îmbunătătită de folosirea abilă a celor 4 instrumente arhitecturale, lumină, formă, culoare, textură. Ca în orice arhitectură destinată unui spațiu cu valențe terapeutice este important să pornești de la nevoile utilizatorului, să folosești principii ale design-ului centrat pe utilizator, adică atât pacient cât și personal medical auxiliar. Un spațiu arhitectural de calitate destinat kinetoterapiei rezultă dintr-o abordare interdisciplinară arhitectkinetoterapeut-medic, centrată pe pacient.

Cuvinte cheie: arhitectură, kinetoterapie, spațiu terapeutic, design user-friendly, instrument arhitectural, design universal, aparate şi accesorii în kinetoterapie 


\begin{abstract}
BACKGROUND: The medical kinetology has as its study object the neuromuscular and articular mechanisms that ensure to the human normal motor activities. In the same time, it is concerned with recording, analyzing and correcting of poor neuro-musculo-articular merchanisms. Kinetotherapy, motion therapy is now differentiated in three components- prophylactic, therapeutic and recovery kinetotherapy and has 9 main objectives: 1 . Relaxation; 2. Correcting posture and body alignment; 3 . Increasing joint mobility; 4 . Increasing muscle strength; 5 . Increasing muscle resistance; 6. Coordination, control and balance; 7. Training to the effort; 8. Respiratory re-education; 9. Reeducation of sensitivity.

Kinetotherapy needs adequate spaces in which to develop, architecture contributing synergistically to increasing the effectiveness of procedures performed in such a therapy.

MATERIALS AND METHODS: There have been identified types of buildings containing dedicated spaces in which kinetotherapy can be practiced: hospitals, clinics, rehabilitation centers, small private centers, therapeutic pools. For this purpose, relevant examples of contemporary architecture from the point of view were selected, highlighting the specific trails for both interior and exterior spaces: Physiotherapy and Rehabilitation Center PUR / Schneider \& Lengauer, Therapeutic Pools for La Esperanza School / FUSTER + Architects, Vandhalla "Egmont Rehabilitation Center / CUBO Arkitekter + Force4 Architects, Rehabilitation Center Groot Klimmendaal / Koen van Velsen, Sport and Fitness Center for Disabled People / Baldinger Architectural Studio, Musholm Extension / AART architects, Center for Individuals with Disabilities / g. bang architecture. The projects of these buildings, project descriptions and photographs of the existing situation were analyzed.
\end{abstract}

RESULTS: Four architectural elements were identified as significant in shaping these types of spaces for motion therapy: light, shape, color and texture. Contemporary architecture dedicated to kinetotherapy uses Universal Design principles, promoting the accessibility of fragile, disabled, elderly or children. The shapes differ, from rectangular spaces to those with a fluid geometry. Light always plays an important role, both natural and artificial, a generous degree of illumination has beneficial effects on the human body, phototherapy positively influencing motion therapy results. The color palette is also important, there are colors that activate like orange, red or others that relax like green, blue. The surface texture on which the work is done plays an essential role, avoiding areas that can cause injuries or landslides. Also, kinesitherapy apparatuses and accessories are important: pulleys, figures and rolls of upholstery, wooden and plastic balance sheets, mattresses, fixed ladders / ladders, occupational therapy tables, sticks and dumbbells. Physical therapy can also be practiced in outdoor spaces, which must also be designed using the same 4 architectural tools.

CONCLUSIONS: The results of kinetotherapy are enhanced by the quality of the space in which they are held. The efficiency of procedures is enhanced by the skillful use of the four architectural tools, light, shape, color, texture tools. As with any architecture designed for a space with therapeutic valences, it is important to start from the user's needs, use principles of user-centered design, that is, both patient and medical staff. A quality architectural space for kinetotherapy results from an interdisciplinary architect-physical therapist-physician approach centered on the patient.

Keywordss: architecture, kinetotherapy, therapeutic space, user-friendly design, architectural tool, universal design, kinetotherapy apparatus and accessories 


\section{BACKGROUND:}

Kinetologia medicală are ca obiect de studiu mecanismele neuromusculare și articulare care asigură omului activitățile motrice normale. În același timp se preocupă de înregistrarea, analizarea și corectarea mecanismelor neuro-musculo-articulare deficitare. Kinetoterapia, terapia prin mișcare se diferențiază astăzi în trei componente- kinetoterapie profilactică, terapeutică și de recuperare şi are 9 obiective principale: 1 . Relaxarea; 2 . Corectarea posturii şi aliniamentului corpului; 3. Creşterea mobilităţii articulare; 4. Creşterea forţei musculare; 5. Creşterea rezistenţei musculare; 6 . Coordonarea, controlul şi echilibrul; 7. Antrenarea la efort; 8. Reeducarea respiratorie; 9. Reeducarea sensibilităţii. (Engrich, 2011)

Kinetoterapia are nevoie de spații adecvate în care să se desfăşoare, arhitectura contribuind în mod sinergic la creșterea eficacității procedurilor efectuate în cadrul unei astfel de terapii.

Kinetoterapeuții ajută persoanele afectate de răniri, boli sau dizabilități prin mișcare și exerciții fizice, terapie manuală, educație și consiliere. Ele mențin sănătatea persoanelor de toate vârstele, ajutând pacienții să gestioneze durerea și să prevină bolile. (http://www.csp.org.uk/your-health/what-physiotherapy)

Profesia contribuie la încurajarea dezvoltării și la facilitarea redresării, permițând oamenilor să rămână în muncă, ajutându-i să rămână independenți cât mai mult timp posibil. (http://www.exploremedicinetv.ro/recuperare-medicala/fizioterapie/sa-vorbim-desprefizioterapia.html)

Fiziokinetoterapia este o profesie bazată pe știință și are o abordare holistică, a întregii persoane asupra sănătăţii și bunăstării, care include stilul de viaţă general al pacientului. În esență, implicarea pacientului în îngrijirea proprie, prin educație, conștientizare, împuternicire și participare la tratamentul lor este un deziderat al acestei specialităţi.

De fiziokinetoterapie se poate beneficia în orice moment al vieții. Fiziokinetoterapia ajută la dureri de spate sau leziuni bruște, gestionează afecțiuni medicale pe termen lung, cum ar fi astmul, și în pregătirea pentru naștere sau un eveniment sportiv. (Stanca, 2012)

\section{MATERIALE S,I METODE:}

Au fost identificate tipuri de clădiri care conțin spații dedicate în care se poate practica kinetoterapie: spitate, clinici, centre de reabilitare, mici centre private, piscine terapeutice. În acest scop, au fost selectate 7 exemple relevante din punctul de vedere al arhitecturii contemporane, evidențiindu-se trasăturile specifice atât pentru spații interioare cât și pentru spații exterioare: Physiotherapy and Rehabilitation Centre PUR / Schneider \& Lengauer, Therapeutic Pools for La Esperanza School / FUSTER + Architects, Vandhalla" Egmont Rehabilitation Centre / CUBO Arkitekter + Force4 Architects, Rehabilitation Centre Groot Klimmendaal / Koen van Velsen, Sport and Fitness Center for Disabled People / Baldinger Architectural Studio, Musholm Extension / AART architects, Center for Individuals with Disabilities / g.bang architecture. Au fost analizate proiectele acestor clădiri, descrierile proiectelor și fotografiile cu situația existentă. 


\section{BACKGROUND:}

The medical kinetology has as its study object the neuromuscular and articular mechanisms that ensure to the human normal motor activities. (Sbenghe, 2008; 1987) In the same time, it is concerned with recording, analyzing and correcting of poor neuro-musculoarticular merchanisms. Kinetotherapy, motion therapy is now differentiated in three components- prophylactic, therapeutic and recovery kinetotherapy and has 9 main objectives: 1. Relaxation; 2. Correcting posture and body alignment; 3. Increasing joint mobility; 4. Increasing muscle strength; 5. Increasing muscle resistance; 6. Coordination, control and balance; 7. Training to the effort; 8. Respiratory re-education; 9. Reeducation of sensitivity.

Kinetotherapy needs adequate spaces in which to develop, architecture contributing synergistically to increasing the effectiveness of procedures performed in such a therapy. (Engrich, 2011; Sbenghe, 2008)

Kinetotherapy needs adequate spaces in which to develop, architecture contributing synergistically to increasing the effectiveness of procedures performed in such a therapy.

Physiotherapists help people affected by injuries, illnesses or disabilities through movement and exercise, manual therapy, education and counseling. They maintain the health of people of all ages, helping patients manage pain and prevent disease. (Marcu, 2007; Sbenghe, 2008; 1987; http://www.csp.org.uk/your-health/what-physiotherapy)

The profession contributes to encouraging development and facilitating recovery, allowing people to remain in work, helping them remain independent as long as possible. (Albu, 2012; Engrich, 2011; http://www.exploremedicinetv.ro/recuperaremedicala/fizioterapie/sa-vorbim-despre-fizioterapia.html)

Physiotherapy is a science-based profession and has a holistic approach to the health and well-being of the entire person, which includes the general lifestyle of the patient. Essentially, patient involvement in self-care, education, awareness, empowerment, and participation in their treatment is a desideratum of this specialty.

Of physiokinetotherapy it can benefit at any time in life. Fiziokinetotherapy helps with back pain or sudden injuries, manages long-term medical conditions such as asthma, and in preparation for a birth or sporting event. (Stanca, 2012)

\section{MATERIALS AND METHODS:}

There have been identified types of buildings containing dedicated spaces in which kinetotherapy can be practiced: hospitals, clinics, rehabilitation centers, small private centers, therapeutic pools. For this purpose, relevant examples of contemporary architecture from the point of view were selected, highlighting the specific trails for both interior and exterior spaces: Physiotherapy and Rehabilitation Centre PUR / Schneider \& Lengauer, Therapeutic Pools for La Esperanza School / FUSTER + Architects, Vandhalla” Egmont Rehabilitation Centre / CUBO Arkitekter + Force4 Architects, Rehabilitation Centre Groot Klimmendaal / Koen van Velsen, Sport and Fitness Center for Disabled People / Baldinger Architectural Studio, Musholm Extension / AART architects, Center for Individuals with Disabilities / g.bang architecture. The projects of these buildings, project descriptions and photographs of the existing situation were analyzed. 


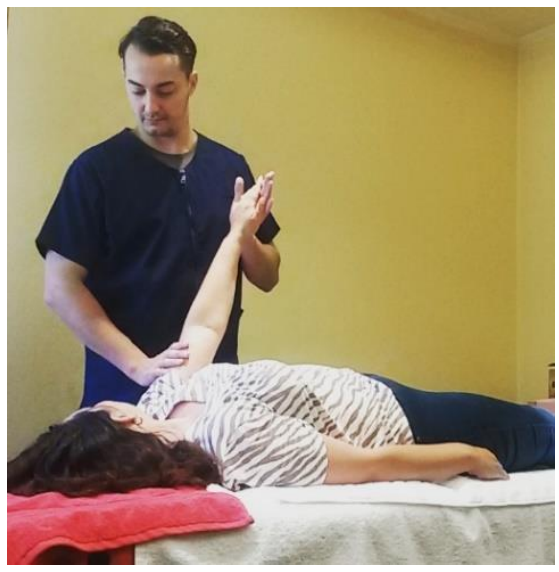

Fig. 1: Exemplificarea unei proceduri de recuperare cu kinetoterapeut Dragoș-Cristian Bogdan;

Exemplification of a recovery procedure with Physical Therapist

Dragoș-Cristian Bogdan

Foto: C) Mihaela Zamfir

\section{Physiotherapy and Rehabilitation Centre PUR / Schneider \& Lengauer, Austria (2004)}

De la arhitect:

Pe lângă fizioterapia clasică (centrul) oferă acum terapie cu exerciții medicale, masaj, o sală de antrenamente și aparatură pentru terapie. Integrarea tuturor acestor servicii a făcut din clădire un model esențial de bune practici. Soluția spațială dezvoltată de Schneider \& Lengauer integrează aceste cerințe și astfel furnizează o organizare simplă, curată și lipsită de bariere pentru toate zonele de lucru.

(trad. ns.) (https://www.archdaily.com/265641/physiotherapy-and-rehabilitation-centre-purschneider-lengauer)

Clădirea are o abordare unitară atât la interior cât și la exterior, un design simplu și funcțional. Lumina joacă un rol esențial în reabilitarea medicală, în spațiul terapeutic în general (Iana, 2015) și acest lucru este evident în sala în care sunt amplasate aparatele destinate exerciţiilor fizice și de kinetoterapie. Acest spațiu beneficiază de 2 pereți complet vitrați care inundă practic în lumină naturală întreg procesul de recuperare. Zona destinată exercițiilor de tip cardio are o terasă în față care este utilizată de asemenea în terapia mersului.

\section{Therapeutic Pools for La Esperanza School / FUSTER + Architects, Puerto Rico (2015)}

De la arhitect:

Piscinele sunt proiectate ca facilități terapeutice pentru copii cu dizabilităţi fizice cu vârste cuprinse între 5 și 16 ani. Facilităţile sunt deschise publicului larg dar vor fi utilizate în special de studenții de la Școala Esperanza, din acest motiv este folosit verdele-galben, verdeleesperanza de la exterior și cuvântul esperanza, adică speranţă scris pe fundul piscinei principale. Este prima structură de acest tip în Puerto Rico."

(trad. ns.) (https://www.archdaily.com/777428/therapeutic-pools-for-la-esperanza-schoolfuster-plus-architects)

Centrul este amplasat în imediata apropiere a unei școli, Școala Esperanza și este conectat printr-un pasaj pietonal de clădire. Și în acest proiect este utilizată lumina naturală ca instrument terapeutic (Iana, 2015), de data aceasta lumina zenitală. Toate cele 3 piscine au contact vizual cu cerul, lumina și cerul fiind în cazul acestui proiect protagoniști importanți în procesul de vindecare, lumina transformând în permanență spațiul și facilitând experiențe diferite. Fiecare piscină este tratată ca o curte interioară, cu inspirație din arhitectura vernaculară la insulei. Terapia care se desfăşoară în aceste piscine implică poziția pacientului, respectiv a copilului cu dizabilități fizice, pe spate, astfel contactul cu priveliștea asupra cerului este permanentă și constituie punctul forte al acestui proiect. Pe lângă principiile Designului 

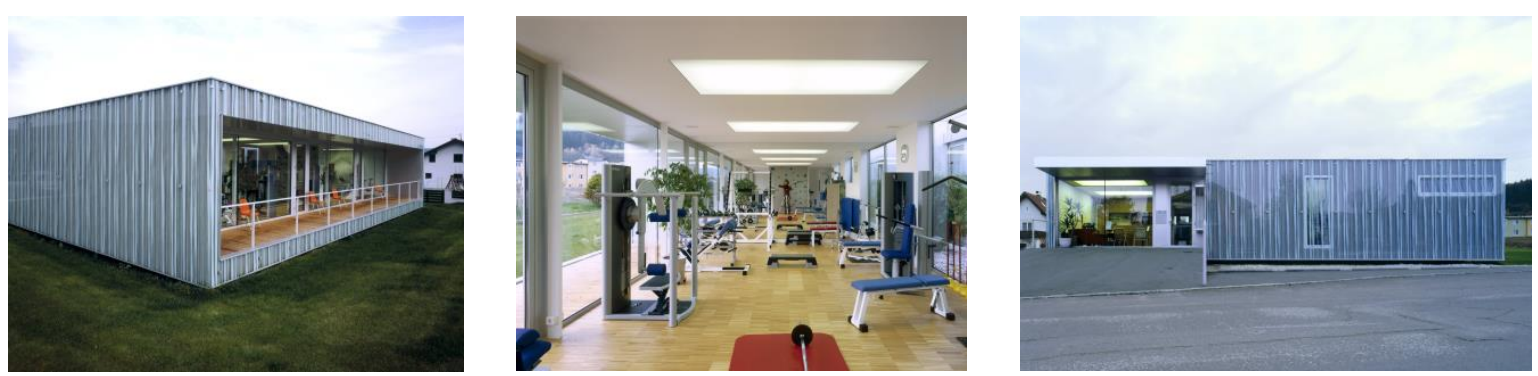

Fig 2: Physiotherapy and Rehabilitation Centre PUR

a) -vedere exterioară 1 / outdoor view 1

b) sala de sport și kinetoterapie / gym and kinetotherapy hall

c) vedere exterioară 2 / outdoor view 2

Sursa/Source: https://www.archdaily.com/265641/physiotherapy-and-rehabilitation-centre-pur-schneiderlengauer

\section{Physiotherapy and Rehabilitation Centre PUR / Schneider \& Lengauer, Austria (2004)}

From the architect:

Besides classical physiotherapy, they now also offer medical exercise therapy, massage, and the sale of training and therapy utensils. The integration of all these services made building a new practice essential. The space solution developed by Schneider \& Lengauer integrates these requirements and therefore provides a simple, smooth and barrier-free organisation of all work areas.

(https://www.archdaily.com/265641/physiotherapy-and-rehabilitation-centre-pur-schneiderlengauer)

The building has an unitary approach both indoors and outdoors, a simple and functional design. Light plays an essential role in medical rehabilitation in the therapeutic area in general (Iana, 2015), and this is evident in the room where physical exercises and kinetotherapy devices are located. This space benefits from 2 full-glazed walls that flood virtually the entire recovery process in natural light. The area for cardio exercises has a front terrace that is also used in walking therapies.

\section{Therapeutic Pools for La Esperanza School / FUSTER + Architects, Puerto Rico (2015)}

From the architect:

The Pools are designed as a therapeutic facility for use by children with physical disabilities between the ages of 5 and 16 years. The facilities are open to the public but will be used primarily by students of La Esperanza School; thus the yellowish- green "verde esperanza" color of the exterior and the word "esperanza" ("hope") written on the bottom of the main pool. This is the first structure of its kind in Puerto Rico.

(https://www.archdaily.com/777428/therapeutic-pools-for-la-esperanza-school-fuster-plusarchitects)

The center is located near the school, the Esperanza School and it is connected by a pedestrian passage by the building. In this project also natural light is used as a therapeutic tool (Iana, 2015), this time the zenith light. All three swimming pools have visual contact with the sky, light and sky being in this project important protagonists in the healing process, the light constantly transforming space and facilitating different experiences. Each pool is treated as an interior courtyard inspired by the vernacular architecture of the island. The therapy that takes place in these pools involves the position of the patient and of the child with physical 
Universal pe care este proiectat desigur acest centru, remarcăm abordarea experiențialistă a spaţiului, accentuarea empowerment-ului pe utilizator. (http://www.archiexpo.com/architecture-design-manufacturer/physiotherapy-swimming-pool5617.html)

Facilitarea conexiunii directe între utilizator și natură-în acest caz particular priveliștea asupra cerului- favorizează procesul de vindecare.
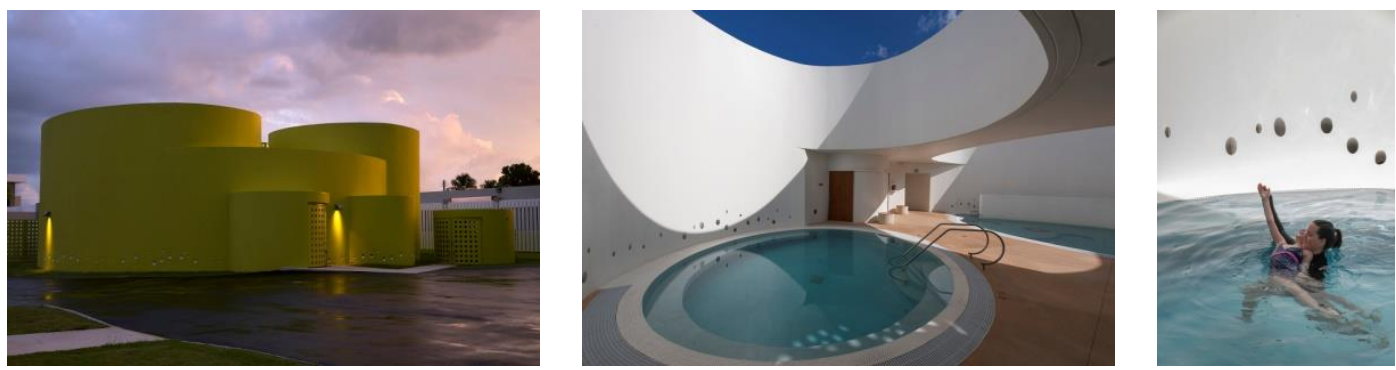

Fig 3: Therapeutic Pools for La Esperanza School

a) vedere exterioară / outdoor view

b vedere curte interioară piscină / interior courtyard swimming pool view

c) procedură terapie în apă / water therapy procedure

Sursa/Source: https:/www.archdaily.com/777428/therapeutic-pools-for-la-esperanza-school-fuster-plusarchitects

\section{3. "Vandhalla" Egmont Rehabilitation Centre / CUBO Arkitekter + Force4 Architects, Danemarca (2013)}

De la arhitect:

Liceul Egmont High este o instituție de top din Danemarca pentru persoanele cu dizabilități. Accesibilitatea pe planuri multiple caracterizează școala și fiecare este dedicat responsabilității pe care o are. Noul centru de reabilitare este un punct de referință pentru zonă și exprimă arhitectural nevoile funcționale ale școlii astfel conferind o identitate nouă vechii clădiri de invăţământ."

(trad. ns.) (https://www.archdaily.com/474130/vandhalla-egmont-rehabilitation-centre-cuboarkitekter-force4-architects)

Planul are poziţionat în centru vestiarele care formează un nod funcţional în jurul căruia gravitează spaţiile terapeutice. Principala facilitate este piscina accesibilă utilizatorilor de scaun rulant care este gândită pentru antrenarea echilibrului. Piscina cu apă caldă pentru hidroterapie are un nivel ajustabil pentru a putea permite desfăşurarea diferitelor exerciţii 2015)

La fel se remarca utilizarea luminii naturale în cadrul procesului de recuperare. (Iana,

Centrul se deschide comunităţii, stimulând spiritul comunitar, oferind posibilitatea combinării antrenamentului cognitiv şi al abilităţilor sociale cu antrenamentul fizic.

\section{Rehabilitation Centre Groot Klimmendaal / Koen van Velsen, Olanda (2011)}

Mizând iar pe importanţa legăturii cu natura în procesul terapeutic, centrul este localizat într-un cadrul natural deosebit, în pădure. Clădirea a fost premiată în 2010 de către Asociaţia Olandeză a Arhitecţilor ca clădirea anului şi tot în acelaşi an a câştigat premiul 1 Hedy d'Ancona Award 2010 pentru excelenţă în arhitectura destinată sănătăţii. 
disabilities on the back, so the contact with the view of the sky is permanent and constitutes the strong point of this project. In addition to the principles of Universal Design on which this center is of course designed, we note the experiential approach to space, the emphasis on empowerment on the user. (http://www.archiexpo.com/architecture-designmanufacturer/physiotherapy-swimming-pool-5617.html)

The facilitating of direct connection between the user and nature-in this particular case the sky view- favors the healling process.
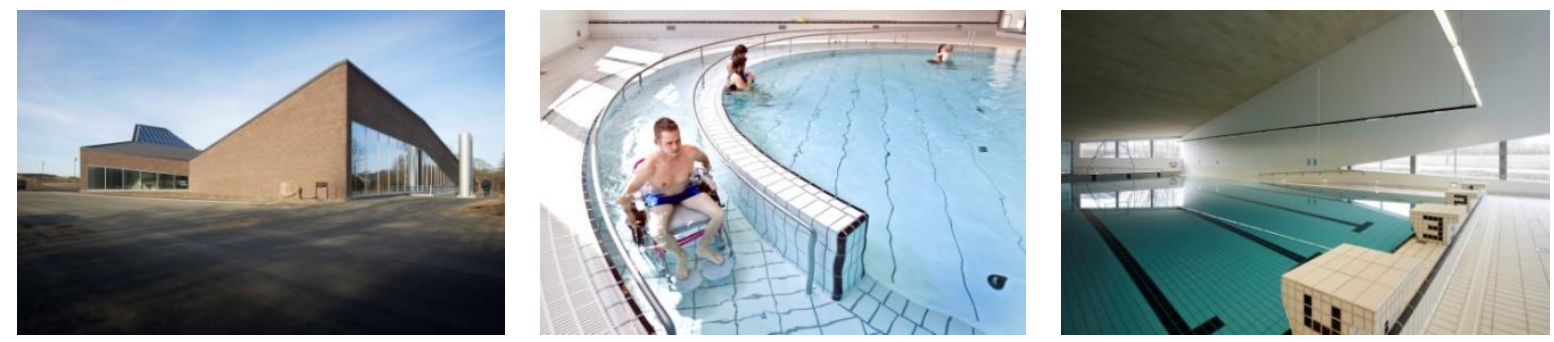

Fig 4: "Vandhalla" Egmont Rehabilitation Centre

a) vedere exterioară / outdoor view

b) vedere piscină pentru persoane cu dizabilități / view of pool for disabled people

c) vedere piscină înot / view of swimming pool

Sursa/Source: https://www.archdaily.com/474130/vandhalla-egmont-rehabilitation-centre-cubo-arkitekterforce4-architects

\section{3. "Vandhalla" Egmont Rehabilitation Centre / CUBO Arkitekter + Force4 Architects, Danemarca (2013)}

From the architect:

The Egmont High School holds a position as Denmark's leading institution for people with physical disabilities. Multifaceted accessibility characterizes the schools entity, and everybody is dedicated to this responsibility. The new rehabilitation centre provides a statement, a landmark that exposes the functional needs of the school architecturally and thus provides a renewed identity to the school's old buildings.

(https://www.archdaily.com/474130/vandhalla-egmont-rehabilitation-centre-cuboarkitekter-force4-architects)

The plan has in center the dressing rooms that form a functional node around which gravitates therapeutic areas. The main feature is the pool accessible to wheelchair users that is designed to drive the balance. The hot water pool for hydrotherapy has an adjustable level to allow developing of various exercises.

The use of natural light is also noted in the recovery process. (Iana, 2015)

The center opens to the community, stimulating the community spirit, offering the possibility of combining cognitive training and social skills with physical training.

\section{Rehabilitation Centre Groot Klimmendaal / Koen van Velsen, Olanda (2011)}

Again relying on the importance of connection with nature in the therapeutic process, the center is located in a special natural setting in the forest. The building was awarded in 2010 by the Dutch Architects Association as the building of the year and in the same year won the Hedy d'Ancona Award 2010 for excellence in architecture for health. 
Clădirea facilitează în permanenţă contactul dintre interior şi exterior prin faţade aproape total vitrate cu diferite grade de transparenţă în funcţie de zona funcţională adăpostită: birouri, facilităţi sportive, piscină, restaurant şi teatru. Este de remarcat ca şi în exemplu anterior deschiderea atât spre pacienţi cât şi spre întreaga comunitate.

"...atât pacientul cât şi clădirea sunt poziţionate în centrul comunităţii." (trad. ns.) (https://www.archdaily.com/126290/rehabilitation-centre-groot-klimmendaal-koen-vanvelsen)

Pe lângă lumina naturală, în cazul acestui proiect se remarcă și cromatica, culori vii precum albastru-cerneală sau portocaliu creeează dinamism și atmosferă caldă. Designul clădirii a fost gândit astfel încât să aibă un aspect prietenos pentru comunitate mai curând decât să aibă un aspect de clădire de sănătate.
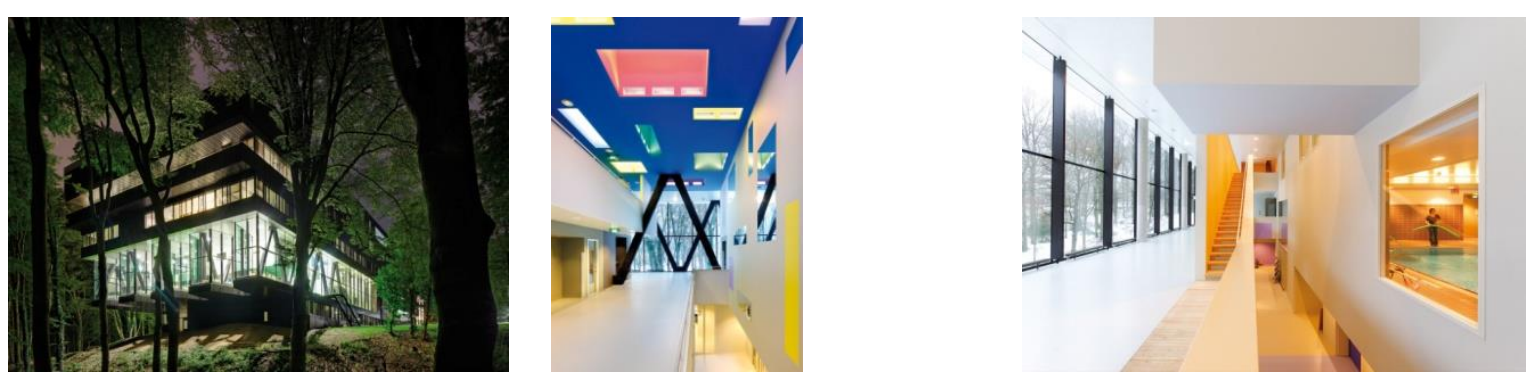

Fig 5: Rehabilitation Centre Groot Klimmendaal

a) vedere exterioară / outdoor view

b) vedere interioară hol / indoor view of the hall

c) vedere sală kinetoterapie / view of kinetotherapy room

Sursa/Source: https://www.archdaily.com/126290/rehabilitation-centre-groot-klimmendaal-koen-van-velsen

\section{Sport and Fitness Center for Disabled People / Baldinger Architectural Studio, SUA (2012)}

De la arhitect:

[Clădirea] îşi îndeplineşte cerinţele şi obiectivele programate, promovând în acelaşi timp sănătatea, starea de bine şi participarea activă la activităţile sportive şi de fitness pentru cel mai larg grup de utilizatori abilitaţi; fie că este utilizator individual, atlet olimpic, un club sportiv local sau echipa naţională.

(trad. ns.) (https://www.archdaily.com/587732/sport-and-fitness-center-for-disabled-peoplebaldinger-architectural-studio).

Aşadar este prezentă aceeaşi concepţie contemporană, adaptativă abilităţilor şi performanţelor fizice diferite, deschiderea spre întreaga comunitate. 
The building permanently facilitates contact between indoor and outdoor through almost completely glazed facades with varying degrees of transparency depending on the sheltered functional area: offices, sports facilities, swimming pool, restaurant and theater. It is noteworthy, as in the previous example, the opening to both patients and the entire community.

"...both patient and building are placed at the centre of the community." (https://www.archdaily.com/126290/rehabilitation-centre-groot-klimmendaal-koen-vanvelsen)

In addition to natural light, this project also features chromatic, vivid colors such as blueink or orange creates dynamism and warm atmosphere. The shape of the building was designed to have a community-friendly appearance rather than having a health building look.
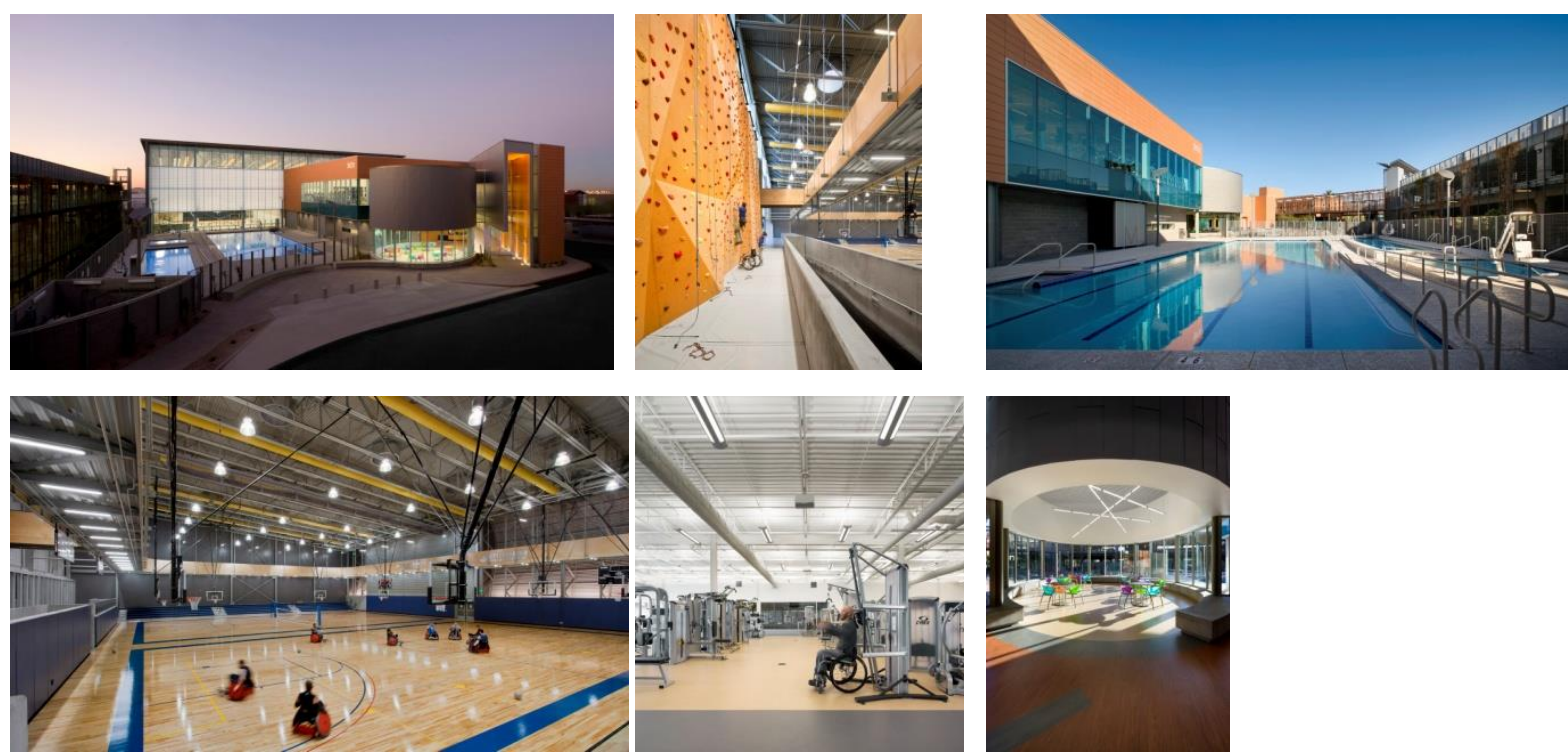

Fig 6: Sport and Fitness Center for Disabled People

a) vedere exterioară / outdoor view

b) vedere zonă de cățărare / view of climbing area

c) vedere piscină exterioară/ view of exterior pool

d) vedere teren baschet persoane cu dizabilități / basketball court for disabled persons view

e) vedere sală fitness persoane cu dizabilități / view of fitness hall for disabled people

f) vedere zonă comunitară / view of community area

Sursa/Source: https://www.archdaily.com/587732/sport-and-fitness-center-for-disabled-people-baldingerarchitectural-studio

\section{Sport and Fitness Center for Disabled People / Baldinger Architectural Studio, SUA} (2012)

From the architect:

The SpoFit fulfills its intended program requirements and goals while promoting health, wellness and the active participation in sport and fitness activities of the widest group of empowered users; be it the individual user, the Olympic athlete, a local Sports Club or National team.

(https://www.archdaily.com/587732/sport-and-fitness-center-for-disabled-people-baldingerarchitectural-studio).

So there is the same contemporary conception, adaptive to different abilities and physical performances, to the whole community. 
Centrul oferă un mediu total care combină în mod inteligent facilităţi sportive şi de recuperare atât la interior cât şi la exterior. Conceptul de wellness este promovat şi este incurajată desfăşurarea de activităţi sportive şi fitness, punându-se accent pe un stil de viaţă activă ca modalitate de prevenţie a bolilor. Utilizatorul este incurajat să facă alegeri în funcţie de abilităţile fizice personale, libertatea de mişcare este totală. Centru oferă un mediu sigur şi sănătos prin spațialitate, lumină și texturi. Se remarcă atenta utilizare a finisajelor antiderapante pentru sala de sport și pentru zona de cățărare.

\section{Musholm Extension / AART architects, Danemarca (2015)}

De la arhitect:

Extinderea aduce la viaţă viziunea noastră despre îmbunătăţirea calităţii vieţii la persoanele cu dizabilităţi pe baza faptului că face spaţii pentru diferenţe. Noi aducem noi experienţe la Musholm- incluzând provocarea abordării tradiţionale spre o arhitectură accesibilă.

(trad. ns.) (https://www.archdaily.com/776148/musholm-extension-aart-architects)

Abordarea în designul acestei clădiri este în spiritul unei multifuncţionalităţi prin concomitenţă în sensul că centrul oferă spaţii diferite pentru experienţe diferite, pentru utilizatori cu abilităţi fizice diferite, păstrând în centrul abordării principiile Designului Universal, accesibilitatea fiind utilizată ca element creativ. (Zamfir, 2017).
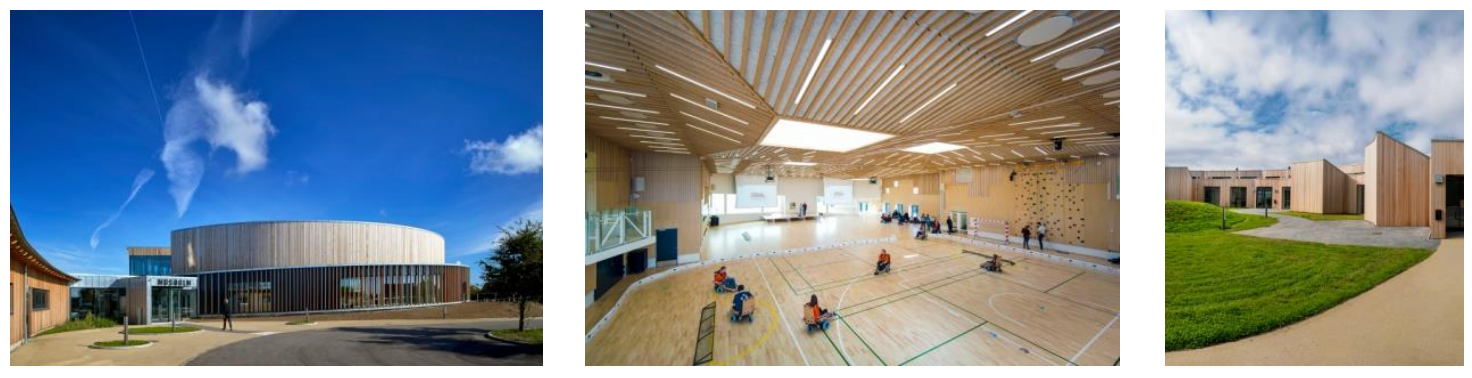

Fig 7: Musholm Extension

a) vedere exterioară 1 / outdoor view 1

b) vedere teren baschet persoane cu dizabilități / basketball court for disabled persons view

c) vedere exterioară 2 / outdoor view 2

Sursa/Source: https://www.archdaily.com/776148/musholm-extension-aart-architects

\section{Center for Individuals with Disabilities / g.bang architecture, Spania (2011)}

De la arhitect:

"Culoarea roșie este un simbol care îi face vizibili...care eliberează de prejudecăți...care accentuează activitatea socială...ne face mai sexy! "(trad. ns.)

Clădirea răspunde nevoii de extindere a unui centru de neuropsihiatrie din Zaragoza. În prezent s-a construit un centru nou de suport pentru tineri cu probleme de comportament și urmează să fie completat cu un modul de ateliere ocupaționale.

Cromatica joacă un rol important în acest caz mai ales la partea de imagine, ajutând la combaterea stigmei care este prezentă de multe ori în cazul clădirilor cu astfel de destinație, bolile și bolnavii psihici sunt încă trataţi discriminatoriu. Roșului curajos de la exterior îi corespunde un alb perfect la interior, anvelopanta fiind ritmată atât la interior cât și la exterior de șarpanta care aduce cu dinamica unui ekg. Aici lumina naturală este mai atent ponderată fiind combinată cu iluminat artificial care pune de asemenea în evidență silueta șarpantei. 
The center offers a total environment that intelligently combines sports and recovery facilities both indoors and outdoors. The concept of wellness is promoted and sports and fitness are encouraged, with an emphasis on an active lifestyle as a way of preventing disease. The user is encouraged to make choices according to personal physical abilities, the freedom of movement is total. Center provides a safe and healthy environment through space, light and textures. Note the careful use of the anti-skidding finishes for the gym and the climbing area.

\section{Musholm Extension / AART architects, Danemarca (2015)}

From the architect:

The extension brings to life our vision of enhancing the quality of life for people with disabilities on the basis of making room for differences. We bring new kinds of experiences to Musholm - including by challenging the traditional approach to accessible architecture.

(https://www.archdaily.com/776148/musholm-extension-aart-architects)

The approach to the design of this building is in the spirit of multifunctionality by concomitance in the sense that the center offers different spaces for different experiences for users with different physical abilities, keeping the principles of Universal Design at the heart of the approach, accessibility being used as a creative element. (Zamfir, 2017).
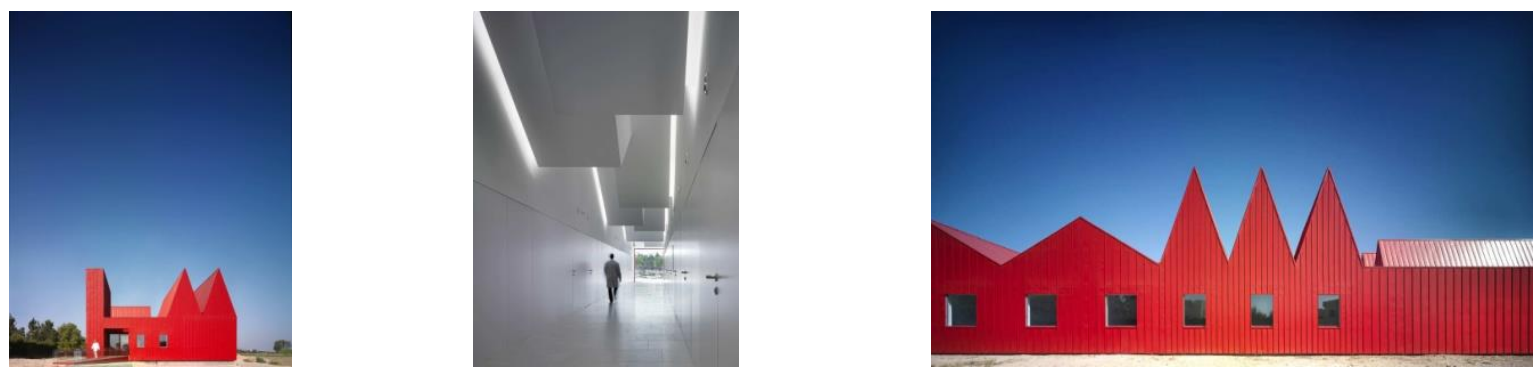

Fig 8: Center for Individuals with Disabilities

a) vedere exterioară 1 / outdoor view 1

b) vedere interioară / interior view

c) vedere exterioară 2 / outdoor view 2

Sursa/Source: https://www.archdaily.com/204841/yound-disabled-moduls-and-workshop-pavillions-g-bangarchitecture

\section{Center for Individuals with Disabilities / g.bang architecture, Spania (2011)}

From the architect:

"The red colour is a symbol that makes them visible... that robs us of prejudice... that emphasizes the social work... makes us more sexy!"

The building meets the need to expand a Zaragoza neuropsychiatric center. A new support center for young people with behavioral problems is being built and is to be completed with a module of occupational workshops.

Chromaticity plays an important role in this case, especially in the image, helping to combat stigma that is often present in buildings with such a destination, illnesses and mentally ill are still treated in a discriminatory way. The courageous redness from the outside corresponds to a perfect white interior, the envelope being rhythmic both inside and outside the gravel that brings with the dynamics of an ekg. Here the natural light is more carefully weighted, combined with artificial lighting that also highlights the silhouette of the roof. 


\section{REZULTATE:}

Patru elemente arhitecturale au fost identificate ca fiind semnificative în conturarea acestor tipuri de spații destinate terapiei prin mișcare: lumina, forma, culoarea și textura. Arhitectura contemporană dedicată kinetoterapiei utilizează principii din Designul Universal, (Zamfir, 2017) promovând accesibilitatea persoanelor fragile, cu dizabilităti, vârstnice sau copii. Formele diferă, de la spații rectangulare (Physiotherapy and Rehabilitation Centre PUR2004, Rehabilitation Centre Groot Klimmendaal-2011) până la cele cu o geometrie fluidă (Therapeutic Pools for La Esperanza School-2015, Musholm Extension-2015). Lumina joacă întotdeauna un rol important, atât cea naturală cât și cea artificială, (Iana, 2015) un grad de iluminare generos are efecte benefice asupra organismului uman, fototerapia influenţand pozitiv rezultatele terapiei prin mișcare. Lumina naturală se dovedește instrumentul cel mai bine și intens utilizat în toate cele 7 cazuri discutate, fiind inclusă în procesul de vindecare. Paleta cromatică este de asemenea importantă, sunt culori care activează precum portocaliu, roșu sau altele care relaxează precum verde, albastru. La exterior cromatica se remarcă în două cazuri, galben-verzui relaxant la Therapeutic Pools for La Esperanza School-2015 și roșu îndrăzneț la Center for Individuals with Disabilities-2015. La interior, se remarcă opțiunea pentru alb dar cu accente cromatice temerare, energizante cum este cazul Rehabilitation Centre Groot Klimmendaal-2011 unde sala de kinetoterapie este colorată în portocaliu iar zona destinată circulației în imediată vecinătate a acestei săli are plafonul albastru inchis cu scafe luminoase în culori calde. Textura suprafețelor pe care se lucrează joacă un rol esențial, au fost evitate suprafețele care pot determina accidentări sau alunecări. Sunt utilizate suprafețe antiderapante. Pentru corectarea tulburărilor de echilibru sunt aparaturi speciale care mimează diferite plane sau obstacole pe care pacientul le poate întâlni, de ex. trepte și rampe. De asemenea, aparatele și accesoriile în kinetoterapie sunt importante: scripeți, figuri și rulouri din tapițerie, plăci de echilibru din lemn și plastic, saltele, scări fixe/spaliere, mese pentru terapie ocupațională, bastoane și gantere. Kinetoterapia este practicată și în spaţii exterioare care de asemenea sunt amenajate utilizând aceleași 4 instrumente arhitecturale.

\section{CONCLUZII:}

Rezultatele kinetoterapiei sunt potențate de calitatea spațiului în care se desfășoară.

Eficiența procedurilor este îmbunătățită de folosirea abilă a celor 4 instrumente arhitecturale, lumină, formă, culoare, textură și accentuăm importanța luminii naturale. Lumina se dovedește a fi instrumentul arhitectural cel mai semnificativ care este utilizat ca parte în procesul de recuperare, de vindecare. Sunt utilizate atât formele rectangulare cât și formele curbe. Formele curbe sunt recomandate mai ales în cazul copiilor și vârstnicilor cu diverse patologii. Culoarea este utilizată mai ales în scopul activării pacientului.

Textura pardoselii este de asemenea importantă. Sunt utilizate pardoseli antiderapante, uşor de întreținut care au capacitatea de a proteja articulațiile, fiind recomandate sistemele poliuretanice. $\quad \mathrm{https}$ ://www.ems-floor.ro/pardoseli-pentru-sali-de-sport-sifitness?gclid=EAIaIQobChMIq-Sry8-v1wIVEomyCh3FzAkAEAAYASAAEgIen_D_BwE.

Ca în orice arhitectură destinată unui spațiu cu valențe terapeutice este important să pornești de la nevoile utilizatorului, să folosești principii ale design-ului centrat pe utilizator, adică atât pacient cât și personal medical auxiliar. (Mazuch, 2005) Un spațiu arhitectural de calitate destinat kinetoterapiei rezultă dintr-o abordare interdisciplinară arhitectkinetoterapeut-medic, centrată pe pacient. 


\section{RESULTS:}

Four architectural elements have been identified as meaningful in shaping these types of spaces for motion therapy: light, shape, color and texture. Contemporary architecture dedicated to kinetotherapy uses Universal Design principles (Zamfir, 2017) promoting the accessibility of fragile, disabled, elderly or children. The forms differ from rectangular spaces (Physiotherapy and Rehabilitation Center PUR-2004, Rehabilitation Center Groot Klimmendaal-2011) to those with a fluid geometry (Therapeutic Pools for La Esperanza School-2015, Musholm Extension-2015). Light always plays an important role, both natural and artificial (Iana, 2015), a generous degree of illumination has beneficial effects on the human body, phototherapy positively influencing motion therapy results. Natural light turns out to be the best and most powerful tool used in all 7 discussed cases, and is included in the healing process.

The color palette is also important, there are colors that activates like orange, red or others that relax as green and blue. The chromatic exterior is noted in two yellow-green relaxation cases at The Esperanza School-2015 Therapeutic Pools and the bold red at the Center for Individuals with Disabilities-2015. Inside, there is the option of white but with energetic darkening accents such as the Rehabilitation Center Groot Klimmendaal-2011 where the kinetotherapy room is colored in orange and the traffic area in the immediate vicinity of this room has a dark blue ceiling with light scales in warm colors. The texture of the work surfaces plays a key role, avoiding areas that can cause injuries or landslides. Non-slip surfaces are used. For correcting equilibrium disorders are special devices that mimic different planes or obstacles that the patient may encounter, stairs and ramps. Also, kinesitherapy apparatuses and accessories are important: pulleys, figures and rolls of upholstery, wooden and plastic balance sheets, mattresses, fixed ladders / ladders, occupational therapy tables, sticks and dumbbells. Physical therapy is also practiced in exterior spaces, which are also arranged using the same 4 architectural tools.

\section{CONCLUSIONS:}

The results of kinetotherapy are enhanced by the quality of the space in which they are held. The efficiency of the procedures is enhanced by the abundant use of the four architectural tools, light, shape, color, texture and emphasizing the importance of natural light. Light is proving to be the most significant architectural tool that is used as part of the recovery, healing process. Both rectangular and curved forms are used. Curved shapes are especially recommended for children and the elderly with various pathologies. Color is mainly used to activate the patient. The texture of the floor is also important. Easy to maintain anti-skidding floors that have the ability to protect joints are used, with polyurethane systems being recommended. $\quad$ https://www.ems-floor.ro/pardoseli-pentru-sali-de-sport-sifitness?gclid=EAIaIQobChMIq-Sry8-v1wIVEomyCh3FzAkAEAAYASAAEgIen_D_BwE.

As with any architecture designed for a space with therapeutic valences (Domash, 2014), it is important to start from the user's needs, use principles of user-centered design, that is, both the patient and the medical staff. (Mazuch, 2005) A quality architectural space for kinetotherapy results from an interdisciplinary architect-physiotherapist-physician approach centered on the patient. 

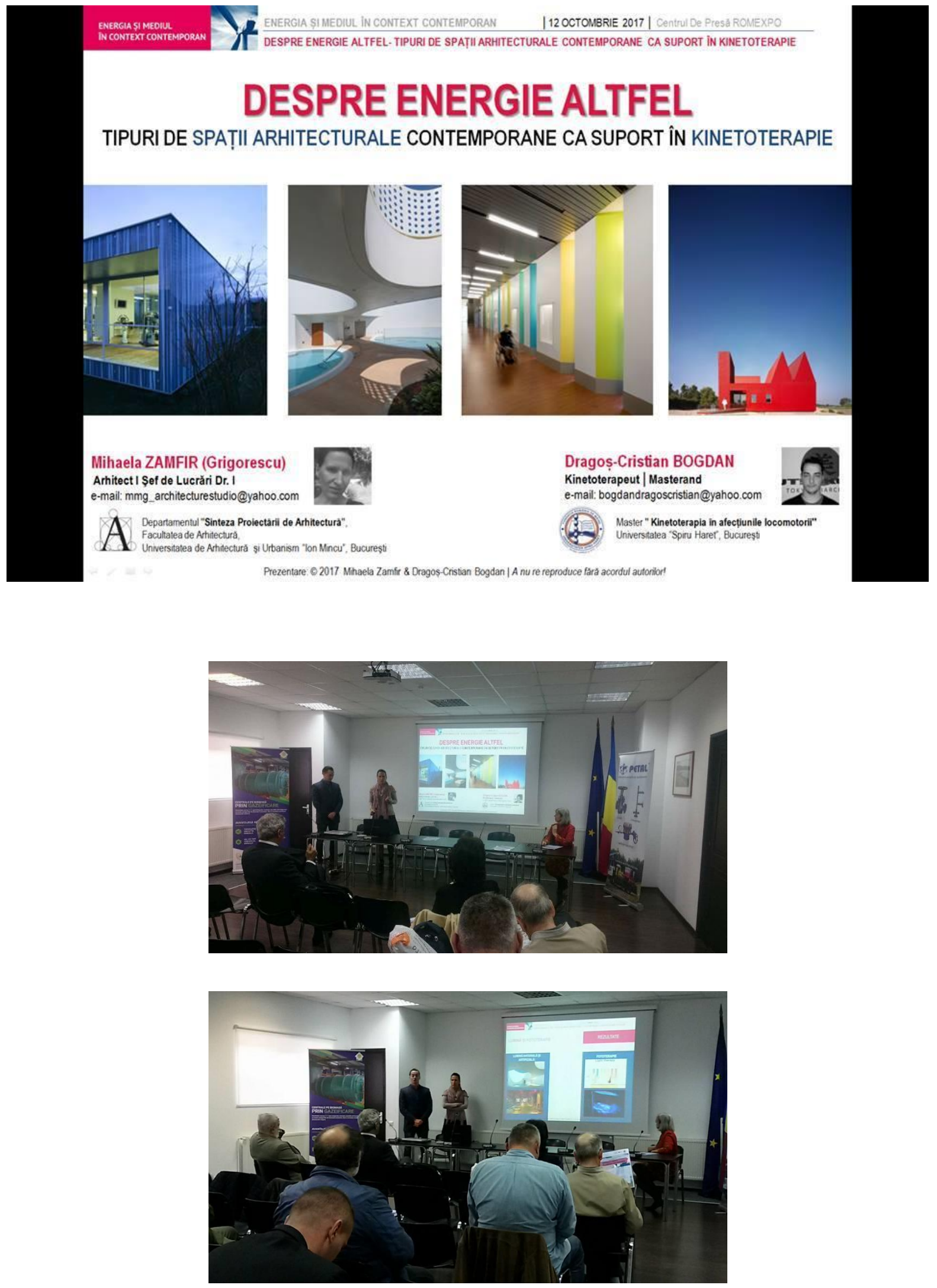

Fig. 9: Fotografii de la conferinţă. Sursa: Arhiva personal a autorilor Photos from the conference. Source: Personal archive of the authors 


\section{Referinţe/References}

Albu, C. 2012. Kinetoterapie: metodologia poziţionării şi mobilizării pacientului. București: Editura Polirom.

Domash L. 2014. "Creating therapeutic "Space": How architecture and design can inform Psychoanalysis". Psychoanalytic Perspectives. 11 (2): 94-111.

Engrich, E., \& Ghinoiu, C. (2011). Kinetoterapia pe înţelesul tuturor: Recuperare în: afecţiuni reumatice, afecţiuni posttraumatice, afecţiuni neurologice, diferite patologii (masaj limfatic). Bucureşti: Editura Medicală.

Iana, C. Coord. (2015). Arhitectura Vindecătoare. București: Ion Mincu.

Marcu, V., Dan, M., Bogdan, R., Mărcuţ, P. \& Bucur, A. 2007. Kinetoterapie = Physiotherapy. Oradea: Editura Universităţii din Oradea.

Mazuch, Richard, and Rona Stephen. 2005. "Creating healing environments: humanistic architecture and therapeutic design". Journal of Public Mental Health. 4 (4): 48-52.

Sbenghe, Tudor. 2008. Kinesiologie: ştiinţa mişcării. Bucureşti: Editura Medicală.

Sbenghe, Tudor. 1987. Kinetologie profilactică, terapeutică şi de recuperare. Bucureşti: Editura Medicală.

Stanca, D., Căciulan, E. (2012). Facilitare-inhibare în kinetoterapie. Ghid practic. Bucureşti: Editura Moroșan.

Zamfir, M., Zamfir, M.V. et ali. (2017). Designul universal într-o abordare interdisciplinarăimportanţa accesibilităţii în centrele pentru persoane vârstnice / Universal design in an interdisciplinary approach- the importance of accesibility in elderly settings. Al 40-lea Congres Naţional de Reabilitare Medicală, Volum de rezumate. Craiova: Editura Medicală.

\section{Referinţe web/Web references}

http://www.csp.org.uk/your-health/what-physiotherapy

http://www.exploremedicinetv.ro/recuperare-medicala/fizioterapie/sa-vorbim-despre-fizioterapia.html https://www.archdaily.com/265641/physiotherapy-and-rehabilitation-centre-pur-schneider-lengauer https://www.archdaily.com/777428/therapeutic-pools-for-la-esperanza-school-fuster-plus-architects http://www.archiexpo.com/architecture-design-manufacturer/physiotherapy-swimming-pool-5617.html https://www.archdaily.com/474130/vandhalla-egmont-rehabilitation-centre-cubo-arkitekter-force4-architects https://www.archdaily.com/126290/rehabilitation-centre-groot-klimmendaal-koen-van-velsen https://www.archdaily.com/587732/sport-and-fitness-center-for-disabled-people-baldinger-architectural-studio https://www.archdaily.com/776148/musholm-extension-aart-architects https://www.archdaily.com/204841/yound-disabled-moduls-and-workshop-pavillions-g-bang-architecture https://www.ems-floor.ro/pardoseli-pentru-sali-de-sport-si-fitness?gclid=EAIaIQobChMIq-Sry8v1wIVEomyCh3FzAkAEAAYASAAEgIen_D_BwE 